\title{
Edukacja kulturalna dorosłych w teorii i badaniach empirycznych w Polsce po 1989 roku - wybrane aspekty
}

\author{
Cultural education of adults in theory and research in Poland \\ after' 89 - selected aspects
}

\begin{abstract}
Streszczenie. Artykuł ma charakter przeglądowy, jego celem jest przedstawienie najbardziej charakterystycznych koncepcji na temat edukacji kulturalnej dorosłych rozwijanych przez polskich przedstawicieli nauk o wychowaniu po roku 1989 oraz zarysowanie jej empirycznego obrazu w oparciu o dostępne wyniki badań. W pierwszej części artykułu autorka opisuje sposoby rozumienia edukacji kulturalnej w ramach polskich klasycznych (tradycyjnych) i nietradycyjnych koncepcji edukacji kulturalnej. Następnie pokazuje, że wraz z upowszechnieniem się szerokiego sposobu pojmowania edukacji jako procesu całożyciowego, dorośli pojawili się w koncepcjach edukacji kulturalnej jako jej uczestnicy i adresaci. Jednakże żadna z polskich koncepcji nie koncentruje się wyłącznie na samych ludziach dorosłych. W drugiej części artykułu zaprezentowane zostały cechy i tendencje edukacji kulturalnej dorosłych w Polsce, zrekonstruowane na podstawie przeprowadzonych w Polsce w ostatnich latach badań empirycznych. W konkluzji autorka podkreśla potrzebę rozwijania badań tego obszaru, który po roku 1989 w Polsce znalazł się poza głównym nurtem zainteresowania andragogów i wymaga pogłębionej eksploracji, pozwalającej zidentyfikować i zrozumieć dokonujące się w jego obrębie przeobrażenia.
\end{abstract}

Słowa kluczowe: edukacja kulturalna dorosłych; koncepcje edukacji kulturalnej; praktyka edukacji kulturalnej.

Summary. The article is a review and its goal is to present the most typical views on the cultural education of adults developed by the Polish researchers since 1989 as well as to outline its empirical picture. In the first part of the article the author describes ways of understanding cultural education within the framework of Polish classical (traditional) and non-traditional concept of cultural education. Then it is shown that with the spread 
of the broad way of understanding education as a lifelong process, adults appeared in the concepts of cultural education as its participants and addressees. However, none of the Polish concepts is focused on the adults only. In the second part of the article there are presented the characteristics and trends of cultural education of adults in Poland, reconstructed on the basis of studies conducted in recent years. In conclusion, the author emphasizes the need to develop research in this area, which after 1989 in Poland, was outside the mainstream of interest of researchers on adult education and requires in-depth test to identify and understand transformation taking place within it.

Key words: cultural education of adults; concepts of cultural education; the practice of cultural education.

\section{Edukacja kulturalna - nowy paradygmat działalności kulturalnej po 1989 roku}

Termin „edukacja kulturalna” pojawił się w refleksji pedagogicznej w Polsce w latach 80., a do jego rozpowszechnienia w dużym stopniu przyczyniły się wówczas publikacje autorstwa Ireny Wojnar. Zgodnie ze stanowiskiem Dzierżymira Jankowskiego (1994) określa on jeden z paradygmatów działalności kulturalnej. Po przełomie społeczno-politycznym w Polsce, wraz z krytyką i marginalizacją upowszechniania kultury, wzrosło zainteresowanie edukacją kulturalną oraz animacją kultury, zarówno wśród teoretyków i badaczy działalności kulturalnej oraz uczestnictwa w kulturze, jak i wśród praktyków. Upowszechnianie kultury na kilkanaście lat niemal zniknęło z dyskursu działalności kulturalnej, a jego miejsce zajęły te właśnie koncepcje (wg Jankowskiego paradygmaty), uznane za bardziej adekwatne wobec demokratyzującej się rzeczywistości. Nie bez znaczenia dla spopularyzowania edukacji kulturalnej były też docierające z zewnątrz impulsy, związane z rozgrywającą się na arenie międzynarodowej debatą nad jej zadaniami oraz rolą kultury we współczesnych procesach rozwojowych. Można tu wymienić m.in. proklamowaną przez ONZ/UNESCO Światową Dekadę Rozwoju Kulturalnego (1988-1997) oraz zadania edukacji kulturalnej, osadzone w szerokiej definicji kultury, ogłoszone w 1992 roku na międzynarodowej konferencji pedagogicznej w Genewie. Zadania te otwierały nowe spojrzenie na edukację kulturalną, gdyż nie ograniczały się jedynie do przygotowania jednostki do kontaktu z wąsko rozumianą kulturą, utożsamianą ze sferą zjawisk artystyczno-intelektualnych, lecz obejmowały wprowadzenie do wiedzy i oceny dziedzictwa kulturowego oraz do uczestnictwa we współczesnym życiu kulturalnym; zaangażowanie w procesy upowszechniania kultu- 
ry; uwrażliwianie na godność kultur i na podstawową więź łączącą dziedzictwo ze współczesnością; edukację estetyczną i artystyczną; kształcenie do wartości moralnych i obywatelskich; przygotowanie do krytycznego korzystania z masowych środków przekazu oraz edukację interkulturową i wielokulturową (Wojnar 2000, s. 174).

\section{Sposoby ujmowania edukacji kulturalnej i jej adresatów w podejściach teoretycznych}

Zwrot ku koncepcji edukacji kulturalnej, jaki nastąpił w latach 90., nie znalazł odzwierciedlenia w obrębie andragogiki. Przegląd publikacji wydawanych po 1989 roku, prowadzi do wniosku, że kwestia edukacji kulturalnej i uczestnictwa w kulturze ludzi dorosłych znalazła się poza głównym nurtem zainteresowania rodzimych badaczy. W czasopismach o profilu andragogicznym tematyka ta pojawia się incydentalnie w trojaki sposób. Po pierwsze, bywa, że stanowi główne zagadnienie artykułu, przybierającego kształt doniesienia $\mathrm{z}$ badań, prezentacji określonego obszaru lub problemu edukacji kulturalnej/uczestnictwa w kulturze dorosłych (np. Przybylska 1999; Olejarz 2001; Depta i in. 2003; Solarczyk 2003; Korzan 2003; Skutnik 2015; Konieczna 2016). W drugim przypadku edukacja kulturalna, ewentualnie uczestnictwo w kulturze bywają wymieniane (rzadko zaś opisywane) jako jeden z obszarów działalności określonych instytucji edukacji dorosłych, szerzej omawianych w danym tekście, np. uniwersytetów ludowych (np. Orkwiszewska 1995/1996; Maliszewski 1999) lub też jako punkt programu wydarzeń naukowych albo naukowo-edukacyjnych prezentowanych w sprawozdaniach (np. Kujawska 2001; Leszczyńska, Rolbiecka 2013). Najrzadziej tematyka ta pojawia się w recenzjach monografii, co wynika z tego, iż pozycji poświęconych edukacji kulturalnej ludzi dorosłych ukazuje się w ostatnich latach niewiele.

Usytuowanie omawianej problematyki poza głównym obszarem aktywności naukowej polskich andragogów w pewnym stopniu wiąże się z faktem, iż edukację kulturalną tradycyjnie odnoszono tylko do dzieci i młodzieży. Stanowisko to ujawnia się w różnym stopniu w koncepcjach edukacji kulturalnej rozwijanych po 1989 roku. Koncepcje te wpisują się w dwa nurty myślenia: tradycyjny (klasyczny) oraz nietradycyjny (Słowińska 2007, 2012), a różni je m.in. przyjęty sposób pojmowania kultury i edukacji, cele oraz właśnie kategoria adresatów - uczestników, wśród których różna pozycja przypadała dorosłym. 
Do podejścia klasycznego należą koncepcje: edukacji humanistycznej Bogdana Suchodolskiego i Ireny Wojnar; wielostronnego wychowania przez sztukę i do sztuki Wojnar; wychowania do uczestnictwa w kulturze symbolicznej i wspomagania wielostronnego rozwoju osobowego człowieka w toku aktywności kulturalnej Dzierżymira Jankowskiego oraz edukacji aksjologicznej w ujęciu personalistycznym autorstwa Katarzyny Olbrycht. Znamienne jest dla nich normatywne myślenie o kulturze, nawiązujące do jej humanistycznej definicji, do idei paidei oraz filozofii platońskiej. Wprawdzie w żadnym z klasycznych ujęć kultura nie bywa redukowana jedynie do sfery wartości wyższych, duchowych, szczególnie cennych, autorzy odwołują się bowiem też do szerszych definicji (socjologicznej, antropologicznej), ale zawsze wyraźnie dokonują hierarchizacji i wartościowania elementów kultury, w konsekwencji wyodrębniając $w$ ramach kultury szerzej pojmowanej sferę wartości i dóbr szczególne cennych („kulturę prawdziwą”). To właśnie tej sfery dotyczy edukacja kulturalna - do tych wartości powinna ona jednostkę wprowadzać i na tych wartościach powinna kształtować jej osobowość. Edukacja $z$ takiej perspektywy przedstawia się także jako proces hierarchiczny, polegający na wznoszeniu się jednostki na coraz wyższe poziomy rozwoju ku ideałowi, wyznaczonemu przez owe szczególnie ważne wartości. Edukacja kulturalna zakłada więc wprowadzanie do tak pojętego świata kultury, internalizowanie jej wartości, a w konsekwencji uszlachetnianie osobowości człowieka oraz sublimację jego uczestnictwa w kulturze.

Z kolei podejście nietradycyjne, za którego przedstawiciela należy uznać Witolda Jakubowskiego, opiera się na niewartościującym myśleniu o kulturze, dialogowym (niehierarchicznym) pojmowaniu edukacji, a w szczególności stawia akcent na uwzględnianie w edukacji kulturalnej obszaru wcześniej z niej wykluczanego - mianowicie kultury popularnej. Ideą jest tu zatem przede wszystkim przygotowanie człowieka do krytycznego, samodzielnego i refleksyjnego poruszania się po szeroko rozumianej kulturze współczesnej (Jakubowski 2001, 2006).

Żadna z wymienionych koncepcji nie jest projektem edukacji kulturalnej dorosłych, przy czym w różnym stopniu i w różnej formie ujawnia się w nich zmiana myślenia o adresatach. Ma to m.in. związek z upowszechnianiem się szerokiego rozumienia edukacji jako procesu całożyciowego, niekoniecznie sformalizowanego i nie zawsze w pełni intencjonalnego. Dochodzi do tego też świadomość głębokich przeobrażeń współczesnych społeczeństw oraz rewolucyjnych wręcz zmian uczestnictwa w kulturze. W efekcie poglądy na temat edukacji kulturalnej i jej adresatów podlegają modyfikacjom, które ogólnie rzecz biorąc, przybierają trzy formy. 
Po pierwsze, w koncepcjach, mających swoje korzenie jeszcze w czasach przedtransformacyjnych, rozszerzeniu uległ krąg adresatów edukacji kulturalnej wcześniej zorientowanej na młode jednostki, tak że stają się nimi wszyscy, bez szczególnego eksponowania dorosłych. Zabieg ten jednak nie wpłynął na kształt samej koncepcji edukacji kulturalnej, jej cele czy projektowane sposoby działania. Dotyczy to m.in. wielostronnego wychowania przez sztukę i do sztuki.

Po drugie, krąg adresatów, uprzednio zawężany do dzieci i młodzieży, zostaje wyraźnie rozbudowany o kategorię ludzi dorosłych, w przekonaniu, że przeobrażenia dokonujące się we współczesnych społeczeństwach czynią konieczną „powszechną” edukację kulturalną, nieograniczoną do młodych pokoleń: „Dynamiczne zmiany kulturalne, będące następstwem licznych procesów technicznych, ekonomicznych i społecznych, oświatowych i politycznych, wymuszają bowiem nieustanne bogacenie kompetencji kulturalnych, których rozwijania nie może zastąpić sama enkulturacja. Ona wymaga wsparcia edukacyjnego w toku całego życia", uzasadnia Jankowski (1999, s. 5). W konsekwencji stworzona przez niego koncepcja zostaje zróżnicowana. Podstawą tego zabiegu jest założenie, że edukacja kulturalna kierowana do dorosłych częściowo powinna realizować inne cele oraz przybierać inny kształt niż edukacja kulturalna dzieci i młodzieży. Zdaniem Jankowskiego decyduje o tym przede wszystkim fakt, iż młode pokolenie w naturalny sposób wrasta w rzeczywistość kulturową, transformującą pod wpływem mediów i nowych technologii. Jest to ich świat, można powiedzieć, że młodzi są w nim tubylcami. Kompetencje do poruszania się po tej dynamicznej rzeczywistości nabywają w drodze spontanicznych procesów enkulturacyjnych. Dla starszych zaś pokoleń zjawiska te jawią się jako nowe i szokujące, dlatego edukacja kulturalna przybiera w ich przypadku postać procesów akulturacji - włączania w obręb nowej dla nich kultury (Jankowski 2006a, s. 37). Zarówno w odniesieniu do dzieci i młodzieży, jak i dorosłych w tak zaprojektowanej edukacji kulturalnej chodzi o kształtowanie kompetencji, które staną się podstawą zaangażowanego, krytycznego, podmiotowego i aktywnego uczestnictwa w kulturze oraz o rozwijanie jednostki jako twórczego i refleksyjnego podmiotu (Jankowski 2006b, s. 33).

I wreszcie po trzecie, koncepcja edukacji kulturalnej konstruowana jest od początku w oparciu o założenie całożyciowego charakteru procesów edukacyjnych oraz w powiązaniu $\mathrm{z}$ aktualnym kontekstem społeczno-kulturowym, wymuszającym odejście od ujmowania jej jako jednokierunkowego procesu transmisji kultury prawomocnej. Przy takim podejściu przybiera 
ona formę dialogu młodych i starszych pokoleń. To trzecie stanowisko obecne jest w poglądach Jakubowskiego:

Edukacja kulturalna tradycyjnie rozumiana koncentrowała się na „przeszczepianiu" kanonu kulturowego młodemu pokoleniu. Zaznajamianiu go ze sposobami odczytań znaków kulturowych. Dorośli podlegali takim samym zabiegom [...]. Takie widzenie zadań edukacji kulturalnej sprzyjało reprodukcji postfiguratywnego charakteru kultury, w której „przeszłość rodziców była przyszłością dzieci". [...] Przyglądając się polskiej rzeczywistości ostatnich lat, łatwo zauważyć, że coraz bardziej nabiera ona kofiguratywnych, czy nawet prefiguratywnych cech. Starsze pokolenie przestaje być czynnikiem transmisji kulturowej [...], należy się pogodzić z możliwością „dwukierunkowości" w edukacji kulturalnej (Jakubowski 2001, s. 29-31).

W tej wizji edukacji kulturalnej to kultura popularna staje się przestrzenią spotkania pokoleń, dialogu i wzajemnego uczenia się.

\section{Edukacja kulturalna dorosłych w badaniach empirycznych}

Niełatwo jest nakreślić empiryczny obraz edukacji kulturalnej dorosłych w Polsce, ponieważ także jako przedmiot badań stopniowo znika ona w ostatnich trzech dziesięcioleciach z pola widzenia andragogów. Andragogicznych przedsięwzięć empirycznych dotyczących tego obszaru i zaznaczających się wyraziście w dyskursie edukacji dorosłych w naszym kraju prawie się nie prowadzi. Również w bardzo niewielkim zakresie andragodzy zajmują się badawczo samym uczestnictwem w kulturze/aktywnością kulturalną ludzi dorosłych, a jeśli tak się dzieje, to częściej rozpoznaniem obejmują osoby na etapie późnej dorosłości, ewentualnie zbliżające się do tego okresu życia (zob. Słowińska 2015) niż dorosłych w wieku średnim.

Znaczący wyjątek stanowią polsko-niemieckie badania edukacji kulturalnej dorosłych, przeprowadzone w latach 2000-2003 na terenie Warszawy, Płocka, Torunia i województwa lubuskiego oraz Brandenburgii i Berlina (zob. Depta i in. 2004; Kargul i in. 2004; Gieseke i in. 2005; Gieseke, Kargul 2005). W badaniach tych, realizowanych w perspektywie porównawczej, zastosowano elastyczne podejście, uwzględniające różnice pomiędzy nimi i dopuszczające odmienne postępowanie badawcze w obu krajach, co zaowocowało bogatymi danymi na temat edukacji kulturalnej dorosłych oraz jej specyfiki w Polsce i Niemczech. Na postępowanie badawcze wdrożone przez polski zespół złożyły się: analiza programów instytucji kultury oraz edukacji 
dorosłych; wywiady z przedstawicielami instytucji kultury i instytucji edukacyjnych; badania ankietowe w instytucjach kultury i instytucjach edukacji; studium przypadku instytucjonalnych form edukacji kulturalnej (zob. Depta i in. 2004; Kargul i in. 2004: Kargul, Börjesson 2005). Elastyczne podejście polegało też na tym, że badacze nie przyjęli z góry konkretnych ram teoretycznych oraz związanych z nimi kategorii analizy i interpretacji, ale dobierali je podczas badań, tak aby były jak najbardziej adekwatne do pozyskanych danych, a także wypracowywali kategorie w oparciu o zebrany materiał. Takie postępowanie pozwoliło m.in. zdefiniować edukację kulturalną jako działania, które (poprzez trzy typy ofert) konstruują trzy portale dostępu do kultury: portal własnej aktywności twórczej (der selbsttätig-kreative Portal), receptywny (der systemmatisch-rezeptive Portal) oraz komunikacyjny, interkulturowy (der verstehend-kommunikative Portal). Celem tak pojmowanej edukacji kulturalnej jest, jak pisze Wiltrud Gieseke, zwiększenie szans uczestnictwa, umożliwienie dorosłym, by się odnaleźli, odzyskali równowagę i doświadczali siebie jako aktywnie działających podmiotów (Gieseke 2010, s. 31, zob. 2003).

Jednocześnie wraz z wycofywaniem się z omawianego pola badań i refleksji teoretycznej pedagogów/andragogów zauważalne staje się w ostatnim dziesięcioleciu wzmożone zainteresowanie nim socjologów oraz kulturoznawców, i to przedstawiciele tych dyscyplin zdają się aktualnie kreować w Polsce dyskusję nad edukacją kulturalną i uczestnictwem w kulturze. Istotną rolę pobudzającą do badawczej aktywności w tych obszarach ma wsparcie finansowe MKiDN. Można nawet mówić o krystalizującym się pewnym nurcie badań. Charakteryzuje go rozszerzanie sposobu pojmowania kultury (ku antropologicznemu), krytyka tradycyjnych, statystycznych badań uczestnictwa w kulturze oraz kluczowych terminów i pojęć, uznawanych za anachroniczne oraz problematyczne. I tak oto termin „uczestnictwo w kulturze" kwestionowany jest jako automatycznie kojarzony z „niejasnymi podziałami" na kulturę wysoką i niską; nieaktualnymi podziałami na „dysponentów” i „odbiorców kultury”, alogicznym podziałem na bierny i czynny udział w kulturze oraz wartościowanie „z góry” form tego uczestnictwa (Fatyga 2014, s. 11). Wreszcie część badaczy odrzuca termin „edukacja kulturalna” i "animacja kultury”/,animacja społeczno-kulturalna”. W ich miejsce proponuje nowe (?) podejście oraz nowe terminy: „edukację kulturową" i „animację kulturową”, uzasadniając, iż lepiej przystają one do zróżnicowanego, zmiennego świata i zdemokratyzowanej kultury: 
edukację kulturową rozumiemy (jako) edukację do bardziej świadomego uczestnictwa kulturze. Dostarcza ona narzędzi zarówno do (a) samodzielnego, krytycznego, pogłębionego rozumienia sensów poszczególnych wytworów kulturowych, jak i do (b) samoświadomego, sprawczego działania w sieci społeczno-kulturowych relacji [...]. Z kolei termin „edukacja kulturalna” odnosi się tylko do tych form edukowania, które opierają się na założeniu, iż istnieje ustalony i niezmienny zestaw wartości, norm, dzieł, umiejętności, których przyswojenie jest warunkiem pełnego uczestnictwa w kulturze, przy czym tę ostatnią najczęściej utożsamia się z „kulturą artystyczną”, a więc rozumie w sposób wąski i selektywny (Krajewski, Schmidt 2014b, s. 9; zob. także Koschany, Skórzyńska 2014).

Trudno się zgodzić z tym stanowiskiem, mając na względzie różnorodność myślenia o edukacji kulturalnej prezentowaną przez polskich pedagogów, w ramach którego, jak zaznaczono, obecne są podejścia mniej lub bardziej tradycyjne, bardziej lub mniej szerokie, ale którym nie sposób przypisać en bloc tak uproszczonego ujmowania sprawy i nieprzystawalności do pluralistycznego świata oraz demokratyzującej się kultury.

Niemniej jednak przyznać należy, że ten nurt badań owocuje licznymi publikacjami i przynosi wiele informacji odnośnie do uczestnictwa w kulturze oraz dokonujących się w jego obrębie przeobrażeń, a przez to wyraźnie ożywia interdyscyplinarną dyskusję na ten temat. Jak już wspomniano, badania, przybierające najczęściej postać diagnoz, przedmiotem penetracji czynią raczej uczestnictwo w kulturze niż edukację kulturalną. Obejmowani są nimi i sami uczestnicy, i podmioty tworzące ofertę. Mają one zarówno zasięg ogólnopolski, jak i regionalny oraz lokalny, podejmowane są w nich także próby wypracowania nowych podejść. Zastosowanie znajdują tu zarówno procedury ilościowe, jak i jakościowe, a w związku z przyjmowaną szeroką definicją kultury i uczestnictwa w kulturze zauważalna staje się tendencja do eksplorowania obszarów, które wcześniej nie były rozpoznane, czyli działalności tzw. nowych instytucji kultury (organizacji pozarządowych, prywatnych firm, grup nieformalnych), przestrzeni aktywności pozainstytucjonalnej, nie ograniczanej do kontaktu ze sferą zjawisk symbolicznych czy też jedynie do udziału w kulturze artystycznej. Część z tych przedsięwzięć badawczych dotyczy ogólnie uczestnictwa w kulturze Polaków (Fatyga i in. 2009; Burszta i in. 2010; Bukraba i in. 2011; Drozdowski i in. 2014) inne koncentrują się na uczestnictwie w kulturze konkretnych grup wiekowych, np. młodzieży (Filiciak i in., 2010), coraz częściej też w centrum zainteresowania znajdują się seniorzy lub szerzej osoby 50+ (Landsberg $i$ in. 2012). 
Najsłabiej zaś rozpoznana pozostaje nadal kategoria ludzi znajdujących się na etapie średniej dorosłości.

Studiując materiał, prezentowany w publikowanych w ostatnim czasie raportach i monografiach, autorstwa przedstawicieli różnych dyscyplin, głównie socjologów i kulturoznawców, w mniejszym stopniu pedagogów, w tym andragogów, można zrekonstruować określone tendencje i cechy właściwe tej sferze praktyki społecznej. Zaznaczyć jednak należy, że stworzony w ten sposób obraz edukacji kulturalnej dorosłych w Polsce jest niepełny, szkicowy, wymaga uzupełnień, na które szansę dać mogą kolejne pogłębione badania.

Wyniki badań (Kargul 2004 i in., Słowińska 2008; Fatyga i in. 2009; Krajewski, Schmidt 2014) pozwalają stwierdzić, że praktycy edukację kulturalną wciąż rozumieją wąsko i wartościująco, przeważnie jako edukację artystyczną, czyli przygotowanie do uprawiania określonej dziedziny sztuki; częściowo też jako edukację przez sztukę, czyli działanie, które wykorzystuje kontakt ze światem zjawisk artystycznych, także twórczy, by rozwijać różne sfery osobowości człowieka oraz przygotowywać go do odbioru i tworzenia sztuki. Badania na terenie woj. lubuskiego, przeprowadzone w ramach wspomnianego polsko-niemieckiego projektu, pokazały, że przedstawiciele instytucji kultury kreują i realizują różne, raczej eklektyczne, koncepcje edukacji kulturalnej, z jednej strony skrojone na miarę warunków danej instytucji i środowiska, a z drugiej odzwierciedlające indywidualne wyobrażenia praktyków o tym, co w edukacji kulturalnej jest ważne. Wszelako owe rozmaite podejścia zbliża to, iż leżący u ich podstaw sposób rozumienia kultury nie zawsze jest w pełni jasny i konsekwentny, i że najczęściej po prostu utożsamiana bywa ona ze sferą sztuki. Samą edukację praktycy traktują też w sposób tradycyjny - jako proces hierarchiczny, polegający na wspinaniu się na kolejne szczeble rozwoju, by zrealizować doskonały wzór, osiągnąć mistrzostwo. Wiąże się to zatem z nastawieniem na efekt końcowy (dzieło), który powinien być zaprezentowany publiczności, uzyskać potwierdzenie swej wartości poprzez wyróżnienia i nagrody. Tak ujmowana edukacja kulturalna dotyczy głównie dzieci i młodzieży, a dorośli jako jej adresaci i uczestnicy pojawiają się marginalnie (Słowińska 2008). W sferze praktyki więc idea uczenia się przez całe życie przebija się powoli. Instytucje kultury orientują większość swoich ofert na młodsze grupy wiekowe, zmiana myślenia o adresatach ujawnia się zaś w poszerzeniu ich kręgu o seniorów. Zatem edukację kulturalną w Polsce oferuje się zasadniczo trzem grupom wiekowym: dzieciom, młodzieży, osobom starszym. Zdecydowanie poza sferą zainteresowania pozostają dorośli w średnim wieku. Potwierdzają to także ba- 
dania, których wyniki przedstawiono w raporcie „Jakiej kultury potrzebują Polacy i czy edukacja kulturalna ją im zapewnia?" (Fatyga i in. 2009). Do nieco innych konkluzji doszli badacze analizujący wnioski o dofinansowanie w ramach programu MKiDN „Edukacja kulturalna”, złożone w roku 2011. Analizy te pokazały bowiem, że seniorzy sytuują się dopiero na trzecim miejscu jako adresaci projektów edukacyjnych i animacyjnych, po dzieciach i młodzieży oraz dorosłych w średnim wieku (Krajewski, Schmidt 2014a, s. 53). Przy czym należy zaznaczyć, iż program ten nie precyzuje dokładnie, co należy pojmować jako edukację kulturalną i wnioskodawcy wszelkie oferty uczestnictwa w kulturze przedstawiają jako oferty edukacji kulturalnej. Stojąc na stanowisku, że „nie wszystko jest edukacją kulturalną”, trudno wyniki tych analiz w tym aspekcie uznać za w pełni miarodajne. To rozpoznanie nie jest też zgodne z wynikami innych badań, wedle których seniorzy obok dzieci i młodzieży to „etatowi odbiorcy” oferty instytucji kultury, dorośli w średnim wieku stanowią zaś grupę najbardziej wycofaną z formalnych układów uczestnictwa w kulturze (Fatyga i in. 2009; Szlendak 2010).

Ważnym wnioskiem płynącym $z$ wielu badań jest więc to, że instytucje kultury raczej pomijają w swojej ofercie ludzi dorosłych w średnim wieku, ale też i oni sami nie są szczególnie zainteresowani edukacją kulturalną. Barbara Fatyga pisze, że ujawniane przez nich potrzeby dotyczą przestrzeni życia codziennego, awansu cywilizacyjnego oraz tzw. konsumpcyjnego stylu życia. Rzadko są to potrzeby samorealizacyjne i społeczne. Badaczka tłumaczy to tym, iż polskie społeczeństwo wychodzi wciąż z cywilizacyjnych zapóźnień (Fatyga i in. 2009). Wydaje się zatem, iż w życiu skoncentrowanym na walce o zapewnienie sobie pożądanego statusu społeczno-ekonomicznego na razie nie ma miejsca na edukację kulturalną. Jednakże przykład krajów wysoko rozwiniętych, np. Niemiec, gdzie oferta edukacji kulturalnej dorosłych jest bogata, a uczestnictwo w tych formach zajęć kształtuje się na wysokim poziomie, pozwala domniemywać, że i w naszym kraju w miarę rozwoju dobrobytu zainteresowanie ludzi dorosłych edukacją kulturalną będzie wzrastać. To przypuszczenie uzasadniałby również teoria wartości materialistycznych i postmaterialistycznych Ronalda Ingleharta (2006).

Niebagatelne znaczenie dla kształtu edukacji kulturalnej dorosłych mają uwarunkowania strukturalne i prawne. W Polce, w odróżnieniu np. od przywoływanych już Niemiec, brakuje aktów prawnych regulujących kwestię edukacji dorosłych. W naszym kraju sieć podmiotów edukacji dorosłych nie jest mocno rozwinięta, a te najważniejsze instytucje oraz organizacje, jak Ośrodek Kształcenia Nauczycieli, Centrum Kształcenia Ustawicznego, Zakład Doskonalenia Zawodowego, Towarzystwo Wiedzy Powszechnej - są ra- 
czej sprofilowane na kształcenie/doskonalenie zawodowe, kursy kwalifikacyjne ewentualnie uzupełnienie wykształcenia ogólnego. Wprawdzie ODN oferuje też kursy doskonalenia dla osób realizujących edukację kulturalną lub wykorzystujących jej elementy, TWP zaś organizuje także warsztaty $i$ kursy artystyczne, ale dzieje się to niezmiernie rzadko. Edukacja kulturalna (głównie skoncentrowana na kulturze ludowej i tradycji regionalnej) jest też jednym $\mathrm{z}$ obszarów działania części uniwersytetów ludowych, tych mianowicie, które orientują się na wspomaganie wielostronnego rozwoju uczestników, a nie jedynie na realizowanie programu reorientacji zawodowej (zob. Rosalska 2004). Wśród instytucji oświaty dorosłych wyjątek stanowią intensywnie rozwijające się ostatnimi czasy Uniwersytety Trzeciego Wieku, dla których edukacja kulturalna seniorów to zadanie podstawowe. W Polsce prowadzenie edukacji kulturalnej (dla wszystkich grup wiekowych) przypada przede wszystkim publicznym instytucjom kultury. Zajmują się tym głównie placówki wielodziedzinowe, czyli domy i centra kultury, dla których jest to jedno z zadań statutowych, równie ważne jak organizowanie imprez kulturalnych, form amatorskiej twórczości artystycznej czy spędzania czasu wolnego dzieci i młodzieży. W domach kultury często też jako sekcje działają UTW lub kluby seniora. Z kolei dla części jednodziedzinowych instytucji, takich jak muzea, biblioteki, galerie, teatry, edukacja kulturalna stanowi sferę działalności dodatkowej. Podmioty te realizują ją obok głównego nurtu działań, związanego $\mathrm{z}$ ich profilem i jedne czynią to w sposób systematyczny, inne zaś incydentalnie lub wcale. W pewnym stopniu także na osoby dorosłe orientuje się część prywatnych podmiotów edukacyjnych, tworzących ofertę komercyjną, są to rozmaite szkoły tańca, szkoły gotowania, akademie twórczości, szkoły muzyczne, szkoły językowe. Inny realizator edukacji kulturalnej to organizacje pozarządowe. Wśród nich należy wskazać na te ukierunkowane na edukację, szczególną rolę odgrywają tu UTW działające jako stowarzyszenia. Ponadto ofertę edukacji kulturalnej tworzą również organizacje nie definiujące się jako stricte edukacyjne, lecz posiadające w statucie edukację jako jedno (z wielu) zadań. Należy jeszcze dodać, że w dużej części pod wpływem programów dotacyjnych, np. programów Ministerstwa Kultury i Dziedzictwa Narodowego „Edukacja kulturalna” (wcześniej „Edukacja”), „Kultura dostępna”, „Kultura ludowa i tradycyjna” (wcześniej „Dziedzictwo kulturowe"), programu Ministerstwa Rodziny, Pracy i Polityki Społecznej Fundusz Inicjatyw Obywatelskch ${ }^{1}$ spektrum i liczba podmiotów tworzących

1 Możliwości pozyskiwania wsparcia na projekty związane z edukacją kulturalną i uczestnictwem w kulturze dają aktualnie liczne programy dotacyjne. Są one oparte o fun- 
ofertę edukacji kulturalnej (w tym edukacji kulturalnej dorosłych) powiększa się. Nie jest to jednak zjawisko jednoznacznie pozytywne, z jednej strony wprawdzie dzięki temu następuje przełamanie monopolu tradycyjnych instytucji kultury, wymuszenie innowacyjnego podejścia, zróżnicowanie i uatrakcyjnienie oferty. Ale z drugiej zaś strony „do gry” wchodzą też podmioty przypadkowe, działające pod „akurat ogłaszane konkursy”, zainteresowane przede wszystkim pozyskiwaniem dotacji, a nie dokonywaniem zmiany w świecie społecznym oraz życiu jednostek, i które swoim sposobem działania przyczyniają się do rozpowszechniania się zjawiska tzw. grantozy oraz dewaluacji projektu jako metody i formy pracy.

Analizowane wyniki badań pokazują także, że w edukacji kulturalnej dominuje oferta o charakterze kreatywnym - zakładająca aktywny, twórczy udział (Solarczyk 2004; Kargul i in. 2004, Krajewski, Schmidt 2014a, Mianowska i in, 2015). Wśród najpopularniejszych dziedzin, których dotyczą zajęcia, znajdują się te związane ze sferą artystyczną: muzyką/śpiewem, teatrem, sztukami plastycznymi. Z kolei w ramach oferty aktywności receptywnej najliczniejszą kategorię stanowią te, które dotyczą historii sztuki i wiedzy kulturoznawczej, a także literatury oraz zajęcia interdyscyplinarne. Dominacja oferty aktywności twórczej przekłada się na popularność określonych form i metod pracy. Są to zatem najczęściej sekcje, kluby, koła zainteresowań, zespoły artystyczne - formy należące do „żelaznego repertuaru” rodzimych domów kultury (Depta i in. 2004; Kargul i in. 2004; Mianowska i in. 2015). W ostatnich latach, co m.in. znowu można przypisać oddziaływaniu rozmaitych programów dotacyjnych, na popularności zyskują projekty i warsztaty. To istotnie różnicuje oblicze edukacji kulturalnej w Polsce (nie tylko dorosłych), ale także w negatywnym sensie, wprowadza bowiem również akcyjność i okazjonalność przedsięwzięć edukacyjnych. Należy zauważyć, że preferowane formy i metody pracy są związane z profilem i typem instytucji, a także $z$ ich tradycją i stylem działania.

dusze publiczne, zarówno krajowej administracji centralnej (np. Rządowy Program na rzecz Aktywizacji Osób Starszych, program Narodowego Centrum Kultury Dom kultury + inicjatywy lokalne) i administracji samorządowej (np. konkursy otwarte na realizację zadań publicznych), jak i europejskie (np. programy Europejskiej Wspótpracy Terytorialnej). Ponadto podmioty zainteresowane realizacją projektów w tym obszarze mogą m.in. uzyskać dofinansowanie w ramach programów czerpiących ze środków prywatnych - przedsiębiorstw oraz organizacji pozarządowych, np. z programu Polsko-Amerykańskiej Fundacji Wolności Seniorzy w Akcji lub Równać szanse - finansującego projekty adresowane tylko do dzieci i/ lub młodzieży (podobnie jak programy Fundacji PZU czy Fundacji Jana Kantego Steczkowskiego $i$ in.). 
Jak wynika z dokonanego tu krótkiego przeglądu, w ożywiającej się od około 10 lat w Polsce dyskusji naukowej nad edukacją kulturalną i uczestnictwem w kulturze głos przedstawicieli nauk o wychowaniu wybrzmiewa raczej słabo. Niewątpliwie większe zaangażowanie w tę problematykę andragogów, sytuujących w centrum zainteresowania uczącego się dorosłego, pozwoliłoby zróżnicować refleksję teoretyczną nad tymi zagadnieniami, a także wzbogacić ich obraz empiryczny, zwłaszcza o perspektywę uczestniczącej w kulturze i edukacji kulturalnej jednostki. Byłoby to tym bardziej cenne poznawczo, że dostępne wyniki badań pokazują, iż uczestnictwo w kulturze podlega aktualnie głębokim przeobrażeniom i stanowi czynnik, który raczej dzieli niż zbliża do siebie pokolenia. Zatem uczestnictwo w kulturze ludzi dorosłych różni się dziś znacznie od uczestnictwa dzieci i młodzieży, a ponadto i sami dorośli stanowią kategorię niezwykle heterogeniczną, więc i w obrębie niej samej uczestnictwo nie jest jednorodne. Toteż badania przeprowadzone $z$ andragogicznej perspektywy, w szczególności pogłębione jakościowe, pozwoliłyby zidentyfikować i zrozumieć nie tylko nowe zjawiska w obrębie uczestnictwa w kulturze i edukacji kulturalnej ludzi dorosłych, a także ich swoistość w porównaniu z innymi kategoriami wiekowymi.

Jednocześnie, na zakończenie należałoby zauważyć, iż choć po 1989 roku nie stworzono w Polsce koncepcji edukacji kulturalnej, w której człowiek dorosły odgrywałby rolę pierwszoplanową, to rozwijane w tym czasie podejścia, ujmujące edukację kulturalną jako proces całożyciowy, wnoszą do dyskusji o niej cenną i potrzebną różnorodność myślenia i to ta różnorodność właśnie powinna być wyraźniej eksponowana oraz kontynuowana, zarówno w teorii, jak i w badaniach. Ponadto wbrew zarzutom anachroniczności i nieprzystawalności, dość arbitralnie formułowanym pod adresem polskich pedagogicznych podejść do edukacji kulturalnej (zob. Fatyga i in. 2009), trzeba stwierdzić, że rozwijane w okresie potransformacyjnym koncepcje zawierają w sobie spory potencjał deskryptywny, eksplanacyjny oraz praktyczny. Ich autorzy wyraźnie nawiązują do współczesnego kontekstu społeczno-kulturowego i odnosząc się do niego konstruują określone wizje edukacji kulturalnej i jej zadań. Wyrazem tego jest zauważalne w refleksji teoretycznej (w przeciwieństwie do praktyki), przechodzenie do ujmowania edukacji kulturalnej jako procesu, w którym nie chodzi tylko o to, by przysposobić człowieka do twórczego lub/i odbiorczego uczestniczenia w kulturze przez wyposażenie go w niezbędne do tego kompetencje. Akcent wyraźnie zostaje położony na to, że edukacja kulturalna wspiera na przestrzeni 
całego życia ogólny rozwój człowieka, jako niezależnego, krytycznego, refleksyjnego podmiotu, potrafiącego osiągnąć równowagę i radzić sobie w migotliwej, pełnej sprzeczności, płynnej rzeczywistości.

\section{Bibliografia}

Bukraba-Rylska I., Burszta W. J. (red.) (2011), Stan i zróżnicowanie kultury wsi i matych miast $w$ Polsce. Kanon i rozproszenie, NCN, Warszawa.

Burszta W. J. i in. (2010), Kultura miejska w Polsce z perspektywy interdyscyplinarnych badań jakościowych, NCN, Warszawa.

Depta H. i in. (2003), Edukacja kulturalna dorostych w placówkach kulturalnych Warszawy, „Rocznik Andragogiczny”, s. 139-151.

Depta H. i in. (red.) (2004), Edukacja kulturalna dorostych. Raport z badań międzykulturowych, Wydział Pedagogiczny UW, Szkoła Wyższa im. P. Włodkowica w Płocku, Warszawa-Płock.

Gieseke W. (2003), Transformacja kultury bez edukacji? Sytuacja edukacji kulturalnej w Europie, „Rocznik Andragogiczny”, s. 127-138.

Gieseke W. (2010), Zur Theorie und Empirie der kulturellen Erwachsenenbildung. Portale zur Kultur, „DIE“ nr 3, s. 31-34.

Gieseke W. i in. (2005), Edukacja kulturalna dorostych w Niemczech. Studium przypadku: Berlin/Brandenburgia, Wydział Pedagogiczny UW, Szkoła Wyższa im. P. Włodkowica w Płocku, Warszawa-Płock.

Gieseke W., Kargul J. (red.) (2005), Europäisierung durch kulturelle Bildung. BildungPraxis- Event, t. 1, 2, Waxman, Münster-New York-München-Berlin.

Inglehart R. (2006), Pojawienie się wartości postmaterialistycznych, [w:] P. Sztompka, M. Kucia (red.), Socjologia. Lektury, Znak, Kraków, s. $334-348$.

Jakubowski W. 2006, Edukacja kulturalna w świecie kultury popularnej, Impuls, Kraków. Jakubowski W., Edukacja i kultura popularna, Impuls, Kraków 2001.

Jankowski D. (1994), Jeden czy wielość paradygmatów działalności kulturalnej, [w:] J. Gajda (red.) Animacja kulturalna jako problem pedagogiczny, Wydawnictwo UMCS, Lublin, s. 19-32.

Jankowski D. (2006a), Aktywność kulturalna dorosłych w sytuacji potężnienia rynku kultury i bezwładu edukacji ogólnej - wyzwania dla edukacji, [w:] B. Jedlewska (red.), Akademickie kształcenie animatorów i menedżerów kultury w Polsce, Verba, Lublin, s. 34-41.

Jankowski D. (2006b), Pedagogika kultury. Studia i koncepcja, Oficyna Wydawnicza „Impuls”, Kraków.

Jankowski D., Wprowadzenie, [w:] D. Jankowski (red.), Edukacja kulturalna w życiu człowieka, Kalisz 1999, s. 5-8.

Kargul J. i in. (2004), Z pradem i pod prad. Lubskie instytucje kultury w nowym ładzie społecznym, Oficyna Wydawnicza Uniwersytetu Zielonogórskiego. 
Kargul J., Börjesson I. (2005), Interkulturelle Forschungsprämissen und Methoden (Vorgehensweise, getrennte Untersuchungen, Gegensatzadäquanz), [w:] Deutsch- polnische Forschungsgruppe (red.), Interkulturelle Betrachtungen kultureller Bildung in Grenzregionen - mit Buckower Empfehlungen, Humboldt Universität zu Berlin, s. 26-32.

Konieczna E. (2016), Senior w kulturze - kultura dla seniora. O kulturowym wzbogacaniu człowieka starszego, „Dyskursy Młodych Andragogów”, t. 17, s. 199-212.

Korzan D. (2003), Seminarium w Płocku. Edukacja dorosłych w Polsce i w Niemczach, „Rocznik Andragogiczny”, s. 173-176.

Kujawska A. (2001), Kto ochroni twórczość ludowa ? - czyli Zimowe warsztaty andragogiczne, Starbienino 11-17 02.2001, „Rocznik Andragogiczny”, s. 233-235.

Leszczyńska A., Rolbiecka M. (2013), Jubileusz 30-lecia Kaszubskiego Uniwersytetu Ludowego, Szymbark - Wieżyca, „Rocznik Andragogiczny”, s. 231-233.

Litawa A. (2016), Chór amatorski jako forma edukacji kulturalnej dorostych na przykładzie krakowskich zespołów chóralnych, Wydawnictwo Naukowe Uniwersytetu Pedagogicznego, Kraków.

Maliszewski T. (1999), Historia i kierunki działalności edukacyjnej Kaszubskiego Uniwersytetu Ludowego, „Rocznik Andragogiczny”, s. 182-187.

Olejarz M. (2001), Udział ludzi dorosłych w Ogólnopolskim Konkursie Recytatorskim, „Edukacja Dorosłych”, nr 3, s. 103-111.

Orkwiszewska A. (1995/1996), Program Katolickiego Uniwersytetu Ludowego i jego realizacja (na przykładzie wszechnicy Ludowej W Lublinie), „Rocznik Andragogiczny", s. 248-254.

Przybylska E. (1999), Edukacja dorostych a muzea jako instytucje kształcenia ustawicznego, „Edukacja Dorosłych”, nr 4, s. 9-21.

Rosalska M. (2004), Katolickie uniwersytety ludowe wobec przemian współczesnej wsi polskiej, Garmond Oficyna Wydawnicza, Poznań.

Skutnik J. (2015), Krzesło w muzeum - o obecności seniorów w muzeum, „Dyskursy Młodych Andragogów", t. 16, s. 265-278.

Słowińska S. (2007), Edukacja kulturalna w Polsce i w Niemczach. Inspiracje - propozycje - koncepcje, Oficyna Wydawnicza „Impuls”, Kraków.

Słowińska S. (2008), Koncepcje edukacji kulturalnej w narracjach kierowników lubuskich domów kultury, [w:] K. Olbrycht i in. (red.), Upowszechnianie kultury wyzwaniem dla edukacji kulturalnej, Wydawnictwo Adam Marszałek, Torun, s. $132--143$.

Słowińska S. (2012), Idee (koncepcje) edukacji kulturalnej, [w:] J. Kargul, Upowszechnianie kultury, animacja, komercjalizacja kultury, PWN, Warszawa, s. 219-241.

Słowińska S. (red.) (2015a), Inicjatywy angażujq̨ce osoby 50+ jako przestrzeń indywidualnego rozwoju i kształtowania kapitału społecznego, Oficyna Wydawnicza Uniwersytetu Zielonogórskiego, Zielona Góra.

Solarczyk H. (2003), Edukacja kulturalna dorosłych w Płocku w ujęciu porównawczym, „Rocznik Andragogiczny”, s. 152-164. 
Solarczyk H., (2004), Edukacja kulturalna dorostych $w$ Polsce i $w$ Niemczech $w$ ujęciu porównawczym, [w:] Depta H. i in. (red.), Edukacja kulturalna dorostych. Raport z badań międzykulturowych, Wydział Pedagogiczny UW, Szkoła Wyższa im. P. Włodkowica w Płocku, Warszawa-Płock, s. 365-376.

Szlendak T. (2010), Aktywność kulturalna, [w:] W. J. Burszta i in., Kultura miejska w Polsce z perspektywy badań interdyscyplinarnych, NCK, Warszawa, s. 112-143.

Wojnar I. (2000), Humanistyczne intencje edukacji, Wydawnictwo Akademickie „Żak”, Warszawa.

Netografia

Drozdowski R. i in. (2014), Praktyki kulturalne Polaków, Toruń, http://www.publicprofits.pl/upl/browser/files/praktyki-kulturalne-polakow-publikacja.pdf (otwarty 02.09.2016).

Fatyga B. (2014), Rekonstrukcja sensu kategorii uczestnictwa w kulturze, [w:] R. Drozdowski i in., Praktyki kulturalne Polaków, Torun, http://www.publicprofits.pl/ /upl/browser/files/ praktyki-kulturalne-polakow-publikacja.pdf, s. 9-12 (otwarty 02.09.2016).

Fatyga B. i in. (2009), Jakiej kultury Polacy potrzebuja i czy edukacja kulturalna im ja zapewnia. Raport o problemach edukacji kulturalnej w Polsce dla MKiDN, http:// www.kongreskultury.pl/library/File/Raportedu/edukacja_kult_raport_ w.pelna\%281\%29.pdf (otwarty 02.09.2016).

Koschany R., Skórzyńska A. (red.) (2014), Edukacja kulturowa. Podręcznik. http:// www.wpek.pl/pi/98258_1.pdf, (otwarty 23.09.2016).

Krajewski M., Schmidt F. (2014a), Animacja/edukacja. Możliwości i ograniczenia edukacji i animacji kulturowej w Polsce. Raport z pierwszego etapu badań, Małopolski Instytut Kultury, Kraków, http://badania-w-kulturze.mik.krakow.pl/files/ /animacja_edukacja.pdf (23.09.2016).

Krajewski M., Schmidt F. (2014b), Animacja/edukacja. Możliwości i ograniczenia edukacji i animacji kulturowej w Polsce. Raport końcowy, Małopolski Instytut Kultury, Kraków, http://e-sklep.mik.krakow.pl/ebooks/animacja-edukacja_raport-koncowy.pdf (otwarty 23.09.2016).

Landsberg P. i in. (2012), Po co seniorom kultura? Badania kulturalnych aktywności osób starszych, Poznań, https://www.academia.edu/2494034/Po_co_seniorom_kultura_Badania_kulturalnych_aktywności_osób_starszych._Raport (otwarty 23.09.2016). 